\title{
A FRAMEWORK FOR JUDICIAL REVIEW OF AN AGENCY'S STATUTORY INTERPRETATION: CHEVRON, U.S.A., INC. V. NATURAL RESOURCES DEFENSE COUNCIL
}

The Suprenie Court of the United States has established two different standards of review in examining an administrative agency's interpretation of the statute it is authorized to adninister"reasonableness" and "rightness." "The Court, in applying the "reasonableness" standard, defers to the agency's interpretation if that interpretation has a reasonable basis in the statute. ${ }^{2}$ In applynig the "rightness" standard, the Court examines the statute and independently determines the "correct" interpretation of the statute. ${ }^{3}$ The issue in the "reasonableness" inquiry is whether the agency's interpretation is a justifiable construction of the statute; the issue in a "rightness" inquiry is whether the agency's interpretation inatches the judicially-determined "correct" interpretation.

The perplexing feature of this duality is that the Supreine Court has never provided any doctrinal guidelines to explain why one test rather than the other should be applied. ${ }^{4}$ A review of Supreine Court cases over

1. See K. Davis, 1982 Supplement to Administrative Law Treatise $\S \S 29.00-6,30.00$ (1982) (standard of review defies encapsulation by formula; sometimes Court substitutes judgment, sometimes rational basis test used) [hereinafter cited as DAVIS, 1982 SupplemENT]; K. DAVIS, Administrative Law Treatise $\$ 30.07$ (Supp. 1970) (Supreme Court cases inconsistent, no opinion attenipts to explain why) [hereinafter cited as DAVIS, 1970 SUPPLEMENT]; $4 \mathrm{~K}$. DAVIS, Administrative LAW Treatise $\S 30.07$ (1958) (Court has uever attempted to explain why it substitutes judgment in one case yet uses rational basis test in others) [heremafter cited as Davis]; JAFFE, Judicial Review: Question of Law, 69 HARv. L. REV. 239, 258-62 (1955) (identifying two types of Suprenie Court cases, one focusing on "correct" construction, the other accepting agency's reasouable interpretation); Note, Perfecting the Partnership: Structuring the Judicial Control of Administrative Determinations of Questions of Law, 31 VAND. L. REV. 91, 111-26 (1978) (reviewing Suprene Court decisions establishing the two standards of review).

2. See, e.g., 4 DAvis, supra uote $1, \S 30.05$ (Court sonietimes accepts ageucy interpretation if it has a "rational basis").

3. See, e.g., id. $\S 30.06$ (Court ofteu substitutes its judgment on construction of statute for agency's interpretation).

4. See, e.g., id. $\$ \S 30.01,30.07$ (Court has never attenipted to provide systenuatic statement of theory that guides its selection of scope of review); Coffman, Judicial Review of Administrative Interpretations of Statutes, 6 W. NEw ENG. L. REV. 1, 3 (1983) (no consisteut rationale explaining why oue approach selected); Schwartz, Administrative Law, 32 N.Y.U. L. REV. 75, 87-88 (1957) 
the past decade reveals an almost random apphication of the two tests. ${ }^{5}$ Although the Court has often stated that in review of agency interpretations of statutes, the existence of an agency construction "sets 'the framework for judicial review," "6 it has never established that analytic framework.

In Chevron, U.S.A., Inc. v. Natural Resources Defense Council, ${ }^{7}$ the Supreme Court may have forged the analytic framework for assessing the validity of an administrative agency's construction of the statute that it is charged with administering. The Court in Chevron announced a twostep method of analysis. ${ }^{8}$ Initially, a reviewing court must deterunine "whether Congress has directly spoken to the precise question at issue." If Congress did not address the precise question, the court must defer to the agency interpretation if that interpretation is "a reasonable accommodation of conflicting pohicies that were cominitted to the agency's care by the statute."10

This note briefly surveys Supreme Court decisions that have estabhished the divergent standards of review, ${ }^{11}$ analyzes Chevron and its two-step method of analysis, ${ }^{12}$ and examines the Court's decisions in the subsequent Securities Industry Association v. Board of Governors cases ${ }^{13}$ and in Chemical Manufacturers Association v. Natural Resources Defense Council. ${ }^{14}$ The note concludes that Chevron, in establishing a framework of analysis for review of an agency imterpretation of the statute in its charge, is a significant decision providing long-awaited guidance to the lower federal courts. ${ }^{15}$

(observing that Court failed to follow recent precedent establishing standard of review and did not distinguish or overrule); Note, supra uote 1, at 114 (no combination of factors adequately explains Court's differing treatment).

5. See infra note 24 .

6. United States v. Vogel Fertilizer Co., 455 U.S. 16, 24 (1982) (quoting United States v. Cartwright, 411 U.S. 546, 550 (1973)).

7. 104 S. Ct. 2778 (1984).

8. Id. at 2781 (reviewing court is confronted with two questions).

9. Id. In this step, a court must determine whether the statutory terms reflect a clear congressional intent. Id. at 2782 n.9. A court makes this determination by employing the "traditional tools of statutory construction." Id..

10. Id. at 2783 (quoting U1rited States v. Shimer, 367 U.S. 374, 383 (1961)).

11. See infra notes $16-31$ and accompanying text.

12. See infra notes $32-77$ and accompanying text.

13. The two cases, Securities Indus. Ass'n v. Board of Governors, 104 S. Ct. 2979 (1984) [hereinafter referred to as Securities Industry I], and Securities Indus. Ass'n v. Board of Governors, 104 S. Ct. 3003 (1984) [hereinafter referred to as Securities Industry II], were announced on June 28, 1984; Chevron was announced on June 25, 1984, Chevron, 104 U.S. at 2778. See infra notes 78-123 and accoinpanying text.

14. 53 U.S.L.W. 4193 (U.S. Feb. 27, 1985). See infra notes $124-96$ and accoinpanying text.

15. See infra notes $197-203$ and accoinpanying text. 


\section{CONFlicting Standards OF REviEW}

Numerous commentators have recognized that the Supreme Court has failed to establish any uniform method of analyzing a statute when the agency charged with administering the statute has already promulgated an imterpretation. ${ }^{16}$ The decisions break down imto two general approaches-those emphasizing a "reasonableness" standard and those mvolving the "rightness" of the administrative interpretation. ${ }^{17}$ Even within these two classifications, the Court is not consistent; the "reasonableness" line of cases reflects a deferential judicial attitude rather than the application of a specific uniform standard of review. ${ }^{18}$

In a case illustrating both standards, NLRB v. Hearst Publications, Inc., ${ }^{19}$ the Court reviewed the National Labor Relations Board's ruling that "newsboys" were "employees" within the meaning of the National Labor Relations Act. ${ }^{20}$ The Court first reviewed the statute, independent of the interpretation presented by the agency, and concluded that Congress had not intended that the definition of "employees" depend upon the employee/independent contractor distinction of state common law. ${ }^{21}$ This portion of the opinion exemplifies a "rightness" approach; the Court reviewed the statute and formulated its own interpretation. The Hearst Publications decision, however, is more often recognized for the "reasonableness" standard announced toward the end of the opinion. ${ }^{22}$ The

16. See infra note 1 .

17. A court employing a "rightness" standard interprets the statute independent of the agency interpretation, treating the case as it would any case that hinges on statutory interpretation. Under the "reasonableness" standard, the agency interpretation carries a presumption of validity and the court defers to that administrative construction if it is reasonable. A court einploying a "reasonableness" approach "looks to see whether the [interpretation] harmonizes with the plain language of the statute, its origin, and its purpose," National Muffler Dealers Ass'n v. United States, 440 U.S. 472, 477 (1979) (emphasis added), and not whether the interpretation is the best reflection of the congressional mandate. Examples of cases where the Supreine Court einployed a "rightness" approach (the terms "substitution of judgment" or "de novo review" are synonymous) are discussed infra in note 24 , while exainples of opinions reciting a "reasonableness" standard are described infra in notes 18 and 24.

18. The "reasonableness" standard has assumed nuany different forms. See, e.g., United States v. Vogel Fertilizer Co., 455 U.S. 16, 24 (1982) (deference owed to agency construction if it "implenent[s] the Congressional mandate in some reasonable nanner" ") (quoting United States v. Correll, 389 U.S. 299, 307 (1967)); Federal Election Comm'n v. Democratic Senatorial Campaign Comm., 454 U.S. 27, 39 (1981) (issue was whether agencies' "construction was 'sufficiently reasonable' to be accepted") (quoting Train v. Natural Resources Defense Council, 421 U.S. 60, 75 (1975)); Ford Motor Credit Co. v. Milhollin, 444 U.S. 555, 565 (1980) (agency construction upheld unless "deinonstrably irrational").

19. 322 U.S. 111 (1944).

20. Id. at 113 .

21. Id. at 124-29. In the Court's opinion, Congress nitended a inuch broader definition of the term. Id. at 129.

22. See, e.g., Coffnan, supra note 4, at 14-15 (citing Hearst Publications as "reasonableness" case in coniparison of "reasonableness" and "rightness" cases). 
Court stated: "where the question is one of specific application of a broad statutory term in a proceeding in which the agency adininistering the statute inust determine it initially [the agency determination] is to be accepted if it has 'warrant in the record' and a reasonable basis in law."23

An examination of recent cases reveals that the Court continues to apply both standards in an apparently randoin fashion; ${ }^{24}$ often an opin-

23. Hearst Publications, 322 U.S. at 131.

24. In the last ten years the Court has deferred to the agencies' interpretations in a wide variety of settings. In Train v. Natural Resources Defense Council, 421 U.S. 60 (1975), the Court found the construction by the Environmental Protection Agency (EPA) of the Clean Air Act "sufficiently reasonable to preclude the Court of Appeals froin substituting its judgment for that of the Agcncy." Id. at 87. In upholding a construction of the Truth in Lending Act pronnulgated by the Federal Reserve Board, Ford Motor Credit v. Milhollin, 444 U.S. 555 (1980), the Court concluded that the "Act is best construed by those who gave it substance in promulgating regulations thereunder" and that "judges ought to refrain froin substituting their own interstitial lawmaking." Id. at 566, 568.

In Immigration \& Naturalization Serv. v. Jong Ha Wang, 450 U.S. 139 (1981) (per curiam), the Supreine Court adinonished a court of appeals for encroaching upon the Attorney General's authority to define "extreme hardship" under the Immigration and Naturalization Act, stating that the Attorney General and his delegates may construe the term "narrowly should they deem it wise to do so." Id. at 145.

The Court has indicated that a Federal Communications Commission (FCC) interpretation of the statutory term "in the public interest" may be sustained if based on a reasoned weigling of competing policies. FCC v. WNCN Listeners Guild, 450 U.S. 582, 596 (1981). In another case the Court held that it was not the function of a court reviewing an Federal Election Comnnission (FEC) construction to "interpret the statute as it thought best," but rather to determine whether the interpretation was " 'sufficiently reasonable' to be accepted." Federal Election Comnn'n v. Democratic Senatorial Campaign Comm., 454 U.S. 27, 39 (1981) (quoting Train v. Natural Resources Defense Council, 421 U.S. 60, 75 (1975)).

Application of the rational basis test is not tantanount to the automatic approval of the agency's construction. In U1rited States v. Vogel Fertilizer Co., 455 U.S. 16 (1982), the Court, reviewing a treasury regulation, first considered whether the agency's interpretation was in harmony with the statutory language. Id. at 25-26. Finding that inquiry inconclusive, the Court then examined the legislative history. Id. at 26-32. The agency's interpretation was found to be inconsistent with both the understanding of Congress as manifested in the House and Senate coininittee reports and the explanation of the provision the agency suggested to Congress at the time the statute was proposed. Id. at 27-32. The Court thus invalidated the regulation as an unreasonable interpretation of the statute. Id. at 19, 34-35.

Many cases support the proposition that a court, in reviewing an agency's construction of the statute it administers, can review the statute, develop its own interpretation, and substitute its judgment for that of the agency. In NLRB v. Highland Park Mfg. Co., 341 U.S. 322 (1951), the Court independently determined whether a specific labor urion was a "national or international labor organization" within the meaning of $\S 9(\mathrm{~h})$ of the National Labor Relations Act, id. at 324-26. In Morton v. Ruiz, 415 U.S. 199 (1974), the Court examined a regulation promulgated by the Bureau of Indian Affairs narrowly limiting the agency's function in providing benefits to Indians on reservations. Id. at 209-10. The Court perceived a broader meaning in the statute that provided the ageney with its general authority and invalidated the agency's regulation: "In order for an agency interpretation to be granted deference, it must be consistent with congressional purpose." Id. at 237 (emphasis added).

If the Court engages in de novo review of the statute, invalidation of the agency's construction does not automatically result. In Northwest Marine Terminal Co. v. Caputo, 432 U.S. 249 (1977), the Court reviewed the decision of a quasi-adjudicatory body within the Department of Labor that had liberally construed the Longshoremen's and Harbor Worker's Coinpensation Act to extend cov- 
ion employing one standard fails to acknowledge the plethora of cases adopting the other standard. ${ }^{25}$ Although resourceful commentators have advanced several models of judicial review in an attempt to explain this inconsistency, each author recognizes significant flaws in his own theory. ${ }^{26}$ The most primitive explanation-that the announced "standard" is simply a device to facilitate the drafting of the opimon- "reasonableness" if the agency interpretation is affirmed, "rightness" if it is invalidated $^{27}$ - accounts for neither the large number of "rightness" cases that validate the agency interpretation nor these cases ostensibly finding an agency's construction "unreasonable."28

The deliberate failure of the Supreme Court to establish a cohesive analytic framework in this area ${ }^{29}$ has left the lower courts witlout gui-

erage to certain injured laborers. See $i d$. at 251-52, 255. Although the Court ignored the agency interpretation in its review of the statute, it independently arrived at the same construction adopted by the agency. Id. at 281. See also NLRB v. Washington Aluminum Co., 370 U.S. 9, 17-18 (1962) (independent analysis of statute and record leads Court to same conclusion as agency); FTC v. Anheuser-Busch, Inc., 363 U.S. 536, 542-45 (1960) (Court's independent view of $\$ 2(a)$ of Clayton Act same as that adopted by FTC); Board of Governors v. Agnew, 329 U.S. 441, $446-47$ (1947) (Court's "plain meaning" interpretation in accord with agency's construction).

25. See, e.g., Highland Park, 341 U.S. at 324-26 (einploying "rightness" analysis and ignoring rational basis test line of cases).

26. Professor Davis identified three factors in an attempt to uncover some consistency in the Court's seemingly sporadic apphication of the rational basis test: comparative qualifications of courts and agencies, extent of power conveyed to the agency, and the generality or specificity of the statutory term. 4 DAvis, supra note $1, \S \S 30.08-30.11$. He has recently indicated, however, that "[p]erhaps . . . the Court prefers its own unguided discretion in each case." Davis, 1982 SuPPLEMENT, supra note $1, \S 30.00$ at 584. Morcover, Professor Jaffe's atteunpts to reconcile the inconsistency of the Court's apphication of the differing standards in his "clear purpose" test, see Jaffe, supra note 1, was, as Professor Davis later recognized, a proposal for future action and not an explanation of past judicial action. See DAVIS, supra note $1, \S 30.07$.

An explanation recently advanced for the Court's use of the rational basis test pivoted on whether the agency's construction extends the agency's preexisting scope of authority. See Coffman, supra note 4. Professor Coffinan has indicated that

[t]he guiding principle seems to be that where a particular interpretation involves an issue as to whether the ageney acted within the scope of its authority, the Court has ordinarily faced and resolved that type of issue in a substantially independent manner. When the agency's scope of authority has been resolved, interpretations of statutory issues within the agency's area of discretion, if reasonable, have been favorably decided in the agency's behalf.

Id. at 12 (footnote omitted). Professor Coffman, however, admits that this "principle" is not without its "aberrations." Id. at 20 n.126.

27. Professors Gellhorn and Robinson have expressed a "suspicion that the rules governing judieial review have no inore substance at the core than a seedless grape," and argne that even when courts articulate a standard of review, it "is seldom useful to understanding the result or predicting future results." Gellhorn \& Robinson, Perspectives on Administrative Law, 75 CoLUM. L. REV. 771, 780 (1975).

28. See supra note 24.

29. In Pittston Stevedoring Corp. v. Dellaventura, 544 F.2d 35 (2d Cir. 1976), Judge Friendly recognized the inconsistent lines of authority, and invited a clarification of the law. Id. at 49 . The Supreine Court, however, declined the invitation, affirming the court of appeals decision in an opin- 
dance. ${ }^{30}$ Although the Court has often stated that the existence of an agency's statutory interpretation "only sets 'the frainework for judicial analysis," "31 the Court has never defined that framework.

\section{CheVRon: The Solution?}

\section{A. Supreme Court Employs Two-Step Analysis.}

In Chevron, U.S.A., Inc. v. Natural Resources Defense Council, 32 the Supreme Court articulated and employed a framework of analysis distimct from either the "rightness" or "reasonableness" approach. At issue in Chevron was an Environmental Protection Agency (EPA) regulation ${ }^{33}$ interpretimg a provision of the Clean Air Act Amendments of 1977.34 Section 172 of the Act provides that in order to construct or operate a new or modified "Inajor stationary source"-a source of air pollution producing inore than 100 tons of pollutants annually -in an area yet to attain federally prescribed air quality standards, the applicant must satisfy several stringent criteria histed in Section $173 .{ }^{35}$ In the challenged

ion that employed a "rightness" analysis while failing to refer to any "reasonableness" cases. Northeast Marine Terminal Co. v. Caputo, 432 U.S. 249 (1977).

30. The Court's failure to provide guidance in this area is evidenced by the wide variety of standards of review employed in the lower courts. See Frank Diehl Farms v. Secretary of Labor, 696 F.2d 1325, 1329 (11th Cir. 1983) (great deference to agency's construction if it involves agency's expertise and lack of judicial expertise); Western Coal Traffic League v. United States, 694 F.2d 378, 383 (5th Cir. 1982) (court may not invalidate agency's imterpretation merely because judges would interpret statute differently); National Wildlife Fed'n v. Gorsuch, 693 F.2d 156, 170 (D.C. Cir. 1982) (deference to agency's construction not uritary concept applied equally to all issues; if some issues involve scientific expertise and others do not, court will grant more deference on former); Olivares $v$. Immigration \& Naturalization Serv., 685 F.2d 1174, 1177 (9th Cir. 1982) (agency interpretation accepted unless demonstrably irrational or clearly contrary to plain and sensible meaning of statute); New Jersey v. Department of Health \& Human Servs., 670 F.2d 1262, 1282 (3d Cir. 1981) (courts remain free to substitute judgment for that of agency); Umion Elec. Co. v. Federal Energy Regulatory Comm'n, 668 F.2d 389, 395 (8tll Cir. 1981) (courts show great deference to agencies' interpretations of statutes, particular deference accorded to Internal Revenue Service); Itlraca College v. NLRB, 623 F.2d 224, 228 ( $2 \mathrm{~d} \mathrm{Cir}$ ) (courts have final word on statutory interpretation), cert. denied, 449 U.S. 975 (1980); Citizens for a Better Env't v. EPA, 596 F.2d 720, 724 (7th Cir. 1979) (deference granted to agency interpretation if such interpretation is consistent with congressional purpose).

31. United States v. Vogel Fertilizer Co., 455 U.S. 16, 24 (1982) (quoting Umited States v. Cartwright, 411 U.S. 546, 550 (1973)).

32. 104 S. Ct. 2778 (1984).

33. Id. at 2780.

34. Clean Air Act Amendments of 1977, Pub. L. No. 95-95, $\S 129,91$ Stat. 685, 746-48 (codified at 42 U.S.C. $\S 7502$ (1982)) (adding $\S 172$ to the Clean Air Act).

35. Before any new or modified "major stationary source" may be built a state agency must determine that (1) there will be sufficient reductions in emissions in the region both to offset the emissions from the proposed source and to allow for finture progress toward attainment of air quality standards, or the increase in emissions will not exceed a statutory allowance for industrial growth; (2) the party requesting approval has certified that its other facilities in the state counply with the state-imiplemented plan (SIP) for reduction of emissions; (3) the SIP is otherwise being implemented; and (4) the proposed source comples with lowest achievable emission rate standards. Id. $\S 129$, 
regulation, the EPA defined "source" by adopting the "bubble concept." The "bubble concept" provides that an entire plant is treated as a "source" and replaceinents of individual pieces of process equipinent are exempt froin application of the stringent criteria as long as the total emission level of the plant is not increased. ${ }^{36}$

Orgamizations representing environmental interests disagreed with this interpretation, arguing that a more mclusive definition was required in order to fulfill the congressional mandate of the clean air laws. ${ }^{37}$ These organizations brouglit suit against the EPA, asserting that Congress intended a definition of "source" that would subject the inaximum ainount of industrial activity to the stringent environmental requireinents of section 173.38 Accordingly, the organizations argued for a definition of "source" that included any pollution-producing unit of equipinent, or aggregate tliereof, that produced more than 100 tons of pollutants annually. ${ }^{39}$

The Suprenie Court reviewed the agency interpretation and, in an

91 Stat. at 748 (codified at 42 U.S.C. $\$ 7503$ (1982) (adding $§ 173$ to the Clean Air Act)). "Major stationary source" is defined by the Act as "any stationary facility or source of air pollutants which directly emits, or has the potential to emit, one hundred tons per year or more of any air pollutant." Id. §301(j), 91 Stat. at 770 (codified at 42 U.S.C. $\$ 7602(\mathrm{j})(1982)$ ).

36. See 46 Fed. Reg. 50,766 (1981). The challenged regulation was promulgated in response to the Reagan Administration's “ '[g]overnment-wide recxamination of regulatory burdens and complexities.' " Chevron, 104 S. Ct. at 2789 (quoting 46 Fed. Reg. 16,281 (1981)). The earhier regulation adopted a bifurcated definition of "source"; the "bubble concept" was used in those provisions of the Aet aimed at maintaining air quality, while "source" was defined as individual pieces of process equipment for provisions dealing with areas that had not attained air quality standards. Chevron, 104 S. Ct. 2788-89 \& n.29 (discussing 45 Fed. Reg. 52,697 (1980)). The EPA argued "that the dual definition 'ean act as a disincentive to new investunent and modernization by discouraging modifications to existing facilities' and 'ean actually retard progress in air pollution control by discouraging replacement of older, dirtier processes or pieces of equipment with new, cleaner ones." "Chevron, 104 S. Ct. at 2789 (quoting 46 Fed. Reg. 16,281 (1981)). The revised regulation simplified the regulatory complexity by giving "source" the "bubble concept" definition in all provisions. See 46 Fed. Reg. 16,281 (1981) (outlining reasons for adopting new regulation, including reduction of confusion and inconsistency).

Because of the unique designation of the concept underlying the EPA's interpretation of "source," Chevron is commonly referred to as "the bubble case." See, e.g., DeLong, The Bubble Case, 10 AD. L. NEws, Fall 1984, at 1.

37. Chevron, 104 S. Ct. at 2780-81, 2790. The Natural Resources Defense Council, Citizens for a Better Environment, and the Northwestern Ohio Lung Association brought suit against the EPA. Natural Resources Defense Council v. Gorsuch, 685 F.2d 718, 718 (D.C. Cir. 1982), rev'd sub nom. Chevron, U.S.A., Inc. v. Natural Resources Defense Council, 104 S. Ct. 2778 (1984). Industry sided with the agency. Id.

38. Chevron, $104 \mathrm{~S}$. Ct. at 2790. The statutory requirements are listed supra at note 35.

39. Chevron, $104 \mathrm{~S}$. Ct. at 2790 . In challenging the EPA regulation, the plaintiff environmental organizations did not allege any procedural infirmity; the challenge was limited to the substantce of the agency's interpretation of the statute. See Natural Resources Defense Council v. Gorsuch, 685 F.2d 718, 720 (D.C. Cir. 1982) ("The controversy centers on the appropriate definition of the word 'source' for the purpose of implementing the statutory scheme."), rev'd sub nom. Chevron, U.S.A., Inc. v. Natural Resources Defense Council, 104 S. Ct. 2778 (1984). 
opinion by Justice Stevens for a unanimous Court, ${ }^{40}$ announced a novel two-step method of analysis. The Court required a reviewing court to first ask "whether Congress has directly spoken to the precise question at issue." 41 If the court, "employing traditional tools of statutory interpretation," 42 determines that the intent of Congress is "clear," then it must effectuate that "unambiguously expressed intent." 43 If, on the other hand, the court determines that the statute and legislative history are silent or annbiguous with regard to the issue, it must uphold the agency's interpretation if it is "based on a permissible construction of the statute."44

Application of this analysis to the Chevron facts was straightforward. The Court found that neither the statute nor the legislative history contained a specific definition of "source" 45 and proceeded to the second step of the analysis, where it determined that the EPA's defimition of "source" did not expand the typical scope of the term. ${ }^{46}$ The Court, noting that the legislative history disclosed that Congress was concerned with both the environmental interest in inproving air quality and the econornic interest in allowing industry to engage in capital iniprovements, ${ }^{47}$ compared the EPA interpretation with these congressional concerns:

the plant wide definition is fully consistent with one of these concerns-the allowance of reasonable economic growth-and, whether or not we beheve it effectively implements the other, we must recognize that the EPA has advanced a reasonable explanation for its conclusion that the regnlations serve the environmental objectives as well. ${ }^{48}$

Summarizing the plaintiffs' case as a challenge that "really centers on the wisdom of the agency's pohicy," the Court upheld the EPA regulation. ${ }^{49}$

40. Although the decision was unanimous, only six justices participated. Justice Marshall and Justice Rehnquist did not participate in the consideration or decision of the case, while Justice O'Connor did not participate in the decision. Chevron, 104 S. Ct. at 2794.

41. Chevron, $104 \mathrm{~S}$. Ct. at 2781.

42. Id. at 2782 n.9.

43. Id. at 2781-82. The first step of the analysis is dispositive of the issue if a court finds the intent of Congress to be clear. Id. at 2781 ("if the intent of Congress is clear, that is the end of the matter"). Thus in soine cases a reviewing court need never examine the "reasonableness" of the agency's interpretation.

44. Id. at 2782 .

45. Id. at 2786, 2791 ("language [of statute] is not dispositive" and "legislative history . . . is unilluminating").

46. Id. at 2790 ("it is certainly no affront to common Enghish usage to take a reference to a major facility or a major source to counote an entire plant as opposed to its constituent parts").

47. Id. at 2786 (citing H.R. REP. No. 294, 95th Cong., 2d Sess. 211, reprinted in 1977 U.S. CODE CONG. \& AD. News 1077, 1290.

48. Id. at 2792 .

49. Id. at 2793-94. 


\section{B. Chevron: Interpretation as Interstitial Lawmaking.}

It is evident that the Chevron Court appled a method of analysis distinct from either the "rightness" or "reasonableness" approaches. Although the Court cited cases employing de novo review in support of the first step of its analysis ${ }^{50}$ and "reasonableness" cases for the second, ${ }^{51}$ the Chevron analysis is more than a sequential arrangement of the two established analytic models. Chevron is distinctive because the Court examined the relationship of Congress, administrative agencies, and the courts, and advanced a coherent framework for structuring judicial review in this area.

The Chevron analysis is patterned after the traditional analytic framework employed by a court reviewing any action of any other governmental branch. ${ }^{52}$ The first-step of the Chevron analysis requires a re-

50. The Court, Chevron, 104 S. Ct. at 2782 n.9, referred to SEC v. Sloan, 436 U.S. 103, 114 (1978) (Court analyzed issue of statutory interpretation as though SEC interpretation carried no inore force than arguinent advanced by any litigant); Federal Maritime Comm'n v. Seatrain Lines, Inc., 411 U.S. 726, 731, 746 (1973) (Court invalidates agency construction even though it recognized statute was "ambiguous in scope"); Volkswagenwerk v. Federal Maritime Comm'n, 390 U.S. 261, 272 (1968) ("[courts] 'are not obliged to stand aside and rubber-stamp their affirmance of administrative decisions they deen inconsistent with a statutory inandate or that frustrate the congressional policy underlying a staute." ") (quoting NLRB v. Brown, 380 U.S. 278, 291 (1965)); NLRB v. Brown, 380 U.S. 278 (1965); FTC v. Colgate-Palmolive, Co., 380 U.S. 374, 385 (1965) (in final analysis, courts must supply the legal standard set forth in words of statute); Social Sec. Bd. v. Nierotko, 327 U.S. 358, 369 (1946) (role of judiciary to define limits of statutory power; agency's interpretation that limited its power was improper); Burnet v. Chicago Portrait Co., 285 U.S. 1, 16 (1932) (Court not bound by administrative construction; agency interpretation "will be taken into account only to the extent that it is supported by valid reasous"); Webster v. Luther, 163 U.S. 331, 342 (1896) (Court did not indicate that administrative agency had promulgated interpretation of statutory language at issue until last paragrapl of eleven-page opimion). The Court in Chevron, 104 S. Ct. at 2782 n.9, also cited Federal Election Comm'n v. Deınocratic Senatorial Campaign Comm., 454 U.S. 27 (1981), which is discussed infra note 51.

51. The Court, Chevron, 104 S. Ct. at 2782 n.11, cited Zerith Radio Corp. v. United States, 437 U.S. 443, 451 (1978) (analysis of regulation reveals that it is "far from unreasonable"); Train v. Natural Resources Defeuse Colmcil, 421 U.S. 60, 75 (1978) (agency interpretation upheld if "suffciently reasonable"); Udall v. Tallman, 380 U.S. 1, 18 (1965) (court must affirm agency interpretation if it is not unreasonable); Unemployment Compensation Comm'n v. Aragon, 329 U.S. 143, 15354 (1940) (reviewing court's function limited; must sustain agency interpretation if it las "reasonable basis in law") (quoting NLRB v. Hearst Publicatious, Inc., 322 U.S. 111, 131 (1944)); McLaren v. Fleischer, 256 U.S. 477, 481-82 (1921) (Court presumed agency construction valid; found no "cogent reasons" to invalidate).

Federal Election Comm'n v. Democratic Senatorial Campaigu Comm., 454 U.S. 27 (1981), was cited by the Court as support for both the first and second steps of its analysis, Chevron, $104 \mathrm{~S}$. Ct. at 2782 n.9, n.11, because that ease presages Chevron to some degree. In Democratic Senatorial Campaign Comm. the Court imitially determined that the statute and its legislative history were ambiguous, 454 U.S. at 31-36, and then shifted its inquiry to whether the agency's construction was "sufficiently reasonable" to inerit approval. Id. at 39 (quoting Train v. Natural Resources Defense Council, 421 U.S. 60, 75 (1975)).

52. A court in reviewing any action of any branch of government first defines the bormdaries of legitimate authority, and then determines whether the action taken falls within that domain. See, 
viewing court to determine whether Congress has exphicitly or implicitly authorized the agency to act in an interpretive role. ${ }^{53}$ The reviewing court exainines the agency's construction only after it has determined that Congress has delegated interpretive authority to the agency. ${ }^{54}$ In the second step, the court determines whether the agency's interpretation has a rational basis $\mathrm{m}$ the statute. ${ }^{55}$ The heart of the Chevron analysis is found in the first step; unfortunately, however, the facts of Chevron do not clearly illuminate the standard of this step. 56

The crucial concept of the first step of the Chevron analysis is that of an imphicit delegation of interpretive authority to the agency. The Court indicated that there is no delegation of authority to interpret the statutory term if Congress has directly spoken to the precise question of interpretation that is at issue and unambiguously expressed its intent as to the resolution of the question. 57 If Congress's expression is ambiguous, on the other hand, then there is an implicit legislative delegation to the agency on the particnlar question. ${ }^{58}$ The standard of the first step apparently demands a great deal of precision froin Congress; in order to prevent a delegation of interpretive authority to an agency, Congress would have to spell out clearly the ineaning of any potentially ainbiguous term.

Although the first step of the Chevron analysis seems to pose an exacting standard, the facts of Chevron hardly press the limits of that standard. The Court recognized that the statutory term at issue"source"-is inherently ambiguous and susceptible to a range of possible disparate interpretations. ${ }^{59}$ Thus, although the statement of the first step appears to demand an exphicit expression of intent from Congress in order to avoid a "delegation" of authority, the apphication of the Chevron facts to the analysis fails to define the "unambiguous expression" standard.

The standard of review of the second step of the Chevron analysis is exceedingly deferential. The reviewing court must uphold the agency interpretation if it is "based on a permissible construction of the statute." 60 In determining whether the EPA regulation was a "permissible construc-

e.g., Monaghan, Marbury and the Administrative State, 83 CoLUM. L. REv. 1, 33 (1983) (little discontinuity between judicial review in administrative law and constitutional law). In revicwing an administrative action, the court must first ask whether the agency had the authority to act, and if the agency is authorized to act, then the court examines the substance of the action. Id. at 6, 25-28.

53. Chevron, $104 \mathrm{~S}$. Ct. at 2781-82.

54. Id.

55. Id. at 2782.

56. See infra text accompanying note 59 .

57. Chevron, $104 \mathrm{~S}$. Ct. at 2781-82.

58. Id. at 2782 .

59. Id. at 2790 (listing the potential definitions of "source" identified by Court of Appeals).

60. Id. at 2782 (emphasis added). 
tion" of section 172, the Court first noted that the agency interpretation was not an "affront to common Enghish usage" of the word "source."61 The level of deference, however, is perhaps best exemplified in the Court's discussion of the agency interpretation's adherence to the policies that motivated the congressional enactment: "whether or not we believe it most effectively implements [the policy of achieving environmental objectives], we must recognize that the EPA has advanced a reasonable explanation for its conclusion . . ." 62 Thus, the second step of the analysis permits a reviewing court only a superficial examination of the agency interpretation; judicial inquiry ceases if the agency can present a smgle reasonable argument supporting its interpretation.

The Chevron Court had to examine the relationship between Congress, admmistrative agencies, and the courts to establish this framework for judicial review. The inherent dilemma in judicial review of an agency's construction of a statute results from the presence of two different interpreters-the court and the agency. ${ }^{63}$ Chevron attempts to resolve this dilemma by providmg that although the judiciary has final authority on issues of statutory construction, ${ }^{64}$ "[t] he responsibilities for assessing the wisdom of such pohicy clioices and resolving the struggle between competing views of the public interest are not judicial ones ...." 65

It is certainly "the province and duty of the judicial department, to say whiat the law is," because "[t]hose who apply the rule to particnlar cases, must of necessity expound and interpret that rule."66 In attempting to provide meaning to a statute, courts endeavor to discern Congress's intent. ${ }^{67}$ But if Congress does not clearly express its intent, then the choice of an interpretation involves selection from a spectrum of ineanings, each representing a specific resolution of competing policies. ${ }^{68}$

61. Id. at 2790 .

62. Id. at 2792 (einphasis added). The EPA argued that its interpretation served environmental objectives because it would remove the disincentives - the requirements of section 173, see supra note 35-to modernization of existing facilities by encouraging replacement of older, dirtier pieces of equipment with newer, cleaner ones. See 46 Fed. Reg. 16,281 (1981). The Court noted that this view had support both in the record developed in the rulemaking process and in independent private studies. Chevron, 104 S. Ct. at 2792 \& nn.36-37.

63. See, e.g., Monaghan, supra note 52, at 2-6 ("deference" implies displacement of judicial judginent; the problem is in determining extent of displacement).

64. Chevron, $104 \mathrm{~S}$. Ct. at 2782 n.9.

65. Id. at 2793.

66. Marbury v. Madison, 5 U.S. (1 Cranch) 137, 177 (1803).

67. See, eg., Philbrook v. Glodgett, 421 U.S. 707, 713 (1975) ("Our objective in a case [involving statutory interpretation] is to ascertain the congressional intent and give effect to the legislative will.").

68. The Court has recognized the legislative process is a battle of "opposing 'forces' of 'radicalism and reaction' [that] are 'averaged' into some 'comproumse measure." " Note, Intent, Clear State- 
The Court has acknowledged that the judiciary is ill-suited to perform this function because it is tantanount to legislating. ${ }^{69}$.

Congress, however, may delegate legislative authority to administrative agencies..$^{70}$ Chevron presumes that if Congress has not expressed its intent on the precise question, then it has implicitly delegated the resolution of competing policy interests to the agencies. ${ }^{71}$ In this manner, Chevron treats some agency "interpretation" as "legislation."72 The role of the court, therefore, is not to interpret the statute, ${ }^{73}$ but to determine the extent of the authority delegated and to ensure that the agency has not overstepped this authority. ${ }^{74}$

ments, and the Common Law: Statutory Interpretation in the Supreme Court, 95 HARV. L. Rev. 892, 900 (1982) (quoting Fullilove v. Klutznick, 448 U.S. 448, 490 (1981) (plurality opinion)); see also City of Mobile v. Bolden, 446 U.S. 55, 91 (1980) (Stevens, J., concurring in judgment) ("legislative process . . . inevitably involves a series of compromises among different group interests"). If legislation is the process of competition among policy interests, then a choice of an interpretation of an unclear statute is a choice among policies.

69. See, e.g., Diamond v. Chakrabarty, 447 U.S. 303, 317 (1980) (Court not coinpetent to entertain arguments addressing the propriety of denying micro-organisms patent protection as matter of policy; resolution of matter of policy requires study that legislative bodies can provide and courts cannot); Regents of Univ. of Cal. v. Bakke, 438 U.S. 265, 296-97 (1978) (Powell, J., announcing the judgment of the Court) (analysis of sociological and political factors to determine harm from past discrimination for variety of minority groups is beyond judicial competence).

70. See, e.g., Yakus v. Umited States, 321 U.S. 414, 425-27 (1944) (delegation to agency to pronulgate regulations fixing "fair and equitable" prices of commodities held constitutional). "Congress is not confined to that inethod of executing its policy which involves the least possible delegation of discretion to administrative officers." Id. at 425-26.

71. Chevron, 104 S. Ct. at 2782, 2793. The Court stated:

"The power of an administrative agency to administer a congressionally created . . p program necessarily requires the formulation of policy and the making of rules to fill any gap left, implicitly or explicity, by Congress." . . . Sometimes the legislative delegation to an agency on a particular question is implicit rather than explicit. In such a case, a court may not substitute its own construction of a statutory provision for a reasonable interpretation made by the administrator of an agency.

Id. at 2782 (quoting Morton v. Ruiz, 415 U.S. 199, 231 (1974) (footnotes omitted)).

72. The portion of the opimion quoted supra note 71 is indicative of the conceptualization of agency interpretation. The Court provides that where Congress has left an implicit gap in the statute, it delegates authority to formulate policy and make rules to fill the gap-in other words, to legislate. See id. By structuring the relationship of courts and agencies in this manner, the issue is no longer the interpretation of the statute, but whether the agency acted within the boundaries of the implicit delegation. Because of this supervisory role, the "court becomes a part of the administrative process rather than a hostile stranger." Note, supra note 1, at 106; see also Monaghan, supra note 52 , at 33 (judicial duty is not to supply all of the relevant ineaning of statutes, but to ensure that agency stays within zone of discretion conferred on it by statute).

73. Indeed, one commentator has suggested that the Suprene Court's present view of statutory interpretation is not a judicial search for the "true" meaning of the statute: "When Congress has not addressed specific issues or has done so ambiguously, statutory interpretation ceases to be solely a problein of discoverimg ineaning. Instead, interpretation becoines an issue of institutional competence and authority." Note, supra note 68, at 899 (footnote omitted).

74. Professor Monaghan has recently argued for just such an approach:

The court's interpretational task is . . . to determine the boimdaries of delegated authority.

A statement that judicial deference is inandated to an administrative "interpretation" of a 
Although the Court has utilized this model in the past, ${ }^{75}$ in those cases the delegation was seen to be intentional. ${ }^{76}$ The thrust of Chevron is that this model applies regardless of whether Congress "consciously" intended the delegation. ${ }^{77} \mathrm{By}$ recharacterizing the analysis froin one of review of an agency interpretation of an ambiguous statute to one of review of an agency's exercise of legitimate law-making authority, Chevron dramatically reshapes the underlying concepts of this area of administrative law.

\section{The Impact of Chevron on Subsequent Cases}

\section{A. Securities Industry.}

Two cases decided shortly after Chevron illuminate the application of the Chevron test although neither explicitly employs the two-step

\footnotetext{
statute is more appropriately understood as a judicial conclusion that some substantive law-making authority has been conferred upon the agency. Where deference exists, the court must specify the boundaries of agency authority, within which the agency is authorized to fashion authoritatively part, often a large part, of the meaning of the statute. By contrast, to the extent that the court interprets the statute to direct it to supply meaning, it interprets the statute to exclude delegated administrative law-making power.
}

Monaghan, supra note 52, at 6 . Monaghan notes that the "case law can be rationalized on such a basis-whether or not all cases were in fact decided with such a perception clearly in mind." Id. at 30.

75. See Federal Election Comm'n v. Democratic Senatorial Campaign Comin., 454 U.S. 27, 3132 (1981) (if statute admits to more than one interpretation, function of court is to determine whether agency "acted within the authority vested in it by Congress"); FCC v. WNCN Listeners Guild, 450 U.S. 582, 596, 604 (1981) (weighing policies to determine meaning of statutory standard is task delegated to agency; court is to determine only whether interpretation is inconsistent with boundaries established in statute); Ford Motor Credit Co. v. Milhollin, 444 U.S. 555, 568 (1980) ("[J]udges ought to refrain from substituting their own interstitial lawmaking for that of [an agency], so long as the latter's lawinaking is not irrational.").

76. See Federal Election Comm'n v. Democratic Senatorial Campaign Comin., 454 U.S. 27, 37 (1981) (Act provides that agency ruling on statute shonld not be reversed unless "contrary to law"); FCC v. WNCN Listeners Guild, 450 U.S. 582, 593-94 (1981) (Act failed to define standard of "public interest, convenience, and necessity" and granted general rulemaking authority to agency; the Court viewed the statute as "a supple instrument for the exercise of discretion by the expert body which Congress has charged to carry out its legislative policy."); Ford Motor Credit Co. v. Milhollin, 444 U.S. 555, 568 (1980) (Court recognized that "language in the legislative history evinces a decided preference for resolving interpretive issues by uniform administrative decision, rather than piecenteal through hitigation").

77. The Court stated:

In this case, the Administrator's interpretation represents a reasonable accominodation of manifestly competing interests and is entitled to deference . . . . Congress intended to aecommodate both interests, but did not do so itself on the level of specificity presented by this case. Perhaps that body consciously desired the Administrator to strike the balance at this lcvel, thinking that those with great expertise and charged with responsibility for admimistering the provision wonld be in a better position to do so; perhaps it simply did not consider the question at this level; and perhaps Congress was unable to forge a coalition on either side of the question, and those on each side decided to take their chances with the schente devised by the agency. For judieial purposes, it matters not which of these things occurred.

Chevron, 104 S. Ct. at 2793 (emphasis added). 
method of analysis. In those two cases, both titled Securities Industry Association v. Board of Governors, ${ }^{78}$ the Supreme Court reviewed the Federal Reserve Board's imterpretations of certain provisions of the Glass-Steagall Act.

In Securities Industry I, the Board determined that sections 16 and 21 of the Glass-Steagall Act did not preclude a commercial bank from underwriting its customers' commercial paper. ${ }^{79}$ Section 16 prohibits commercial banks from underwriting "securities or stock," 80 and section 21 prohibits any institution involved in underwriting "stocks, bonds, debentures, notes, or other securities" froun engaging in commercial banking. 81 The Board concluded that because commercial paper was a nonequity instrument, the proscriptions of sections 16 and 21 did not apply. 82

In setting the standard of review, the Supreme Court stated that it must reject the Board's construction of the statute if it was "inconsistent with the statutory mandate," 83 but, nonetheless, the Board's interpretation was "entitled to substantial deference." 84 Analysis of the statute and its legislative history revealed that Congress, in separating commercial banking and investinent banking, was concerned with two issues. First, Congress was aware of the risks involved in the securities business and the subsequent erosion of public confidence in a depository institution that loses money from an "imprudent investinent" in "speculative securi-

78. Securities Indus. Ass'n v. Board of Governors, 104 S. Ct. 2979 (1984) [Securities Industry I], and Securities Indus. Ass'n v. Board of Governors, 104 S. Ct. 3003 (1983) [Securities Industry II].

79. See Securities Industry I, 104 S. Ct. at 2982. "Commercial paper" consists of unsecured, short-term promissory notes, issued by business entities and made payable to the bearer. Coinunent, The Commercial Paper Market and the Securities Acts, 39 U. CHI. L. Rev. 362, 363 (1972) (discussing characteristics of "commercial paper"). The instruments generally inature within thirty to ninety days, and typically are rolled-over to the same or differcnt investor at the market rate at the time of maturity. Id. at 363-64.

80. Banking Act of 1933 , ch. $89, \S 16,48$ Stat. $162,184-85$ (codified as amended at 12 U.S.C. $\S 24$ (1982)).

81. Banking Act of 1933, ch. $89, \S 21(\mathrm{a})(1), 48$ Stat. 162,189 (codified at amended at 12 U.S.C. $\S 378$ (a)(1)(1982)). The Board noted that although commercial paper fit within the broad categories of "notes" or "securities," Congress had intended only to prohibit commercial banks froin engaging in investment transactions and accordingly limited the terms to finaneial instrunents that evidenced an investment transaction. Securities Industry I, 104 S. Ct. at 2982.

82. Id. The Board adopted a functional interpretation of the Glass-Steagall Act, stating that it "was plainly designed to kecp banks froin engaging in the investment banking business, not to prohibit banks from performing the traditional function of banks." Petition for Certiorari at 65a, 74a, Securities Industry Ass'n v. Board of Governors, 104 S. Ct. 2979 (1984) (reprint of Board's decision). The Board determined that the commercial paper being sold appeared to evidence transactions more like commercial lending than the sale of investments. Id. at 78a.

83. $104 \mathrm{~S}$. Ct. at 2983.

84. Id. 
ties." 85 Second, Congress was cognizant of the conflict of interest arising if a single institution acts as an "important source of financial advice . . . [on] how best to issue equity or debt securities" ${ }^{96}$ while simultaneously entertaining the prospect of potential pecuniary gain fron the niethod of issuance. ${ }^{87}$ The Court concluded that "[t]hrough flat prohibitions, the Act sought to 'separat[e] as conipletely as possible commercial from investınent banking," "88 and thus was intended to be "a strong prophylaxis." 89

The Court then examined the statutory terms at issue, concluding that nothing in the statute inandated a narrow interpretation. ${ }^{90}$ Moreover, because the definition of "security" in other statutes enacted contemporaneously with the Glass-Steagall Act included commercial paper and provided exphcit exemptions if a specific provision was not intended to apply to commercial paper, it was clear that Congress understood "security" to enconupass commercial paper. ${ }^{91}$ Because the Board's interpretation was thus inconsistent with the plain language of the statute, that portion of its opimion was invalidated. 92

The dissent, ${ }^{93}$ in setting out the standard of review, noted that the "relevant statutes are far froin clear" and thus "the Board's interpretation . . . must be sustained unless it is unreasonable."94 The dissent first noted that the statutory language had no "plain meaning" because the terms "securities" and "notes" are not defined by the statute and are not

85. Id. at 2984.

86. Id. Congress observed that commercial bankers "routinely advise[d] clients on a variety of financial matters such as whether and low best to issue equity or debt securities." Id.

87. Id. ("Congress concluded that it was unrealistic to expect a banker to give impartial advice about suclı matters if lie stands to realize as a profit from the underwriting or distribution of securities.").

88. Id. at 2985 (quoting Board of Governors v. Investınent Co. Inst., 450 U.S. 46,70 (1981)).

89. Securities Industry I, 104 S. Ct. at 2986.

90. Id. at 2987.

91. Id. The Court examined provisions of the Securities Act of 1933, cl1. 38, 48 Stat. 74 (codified as amended at 15 U.S.C. $\$ \$ 77 a-77 a a(1982)$ ); the Securities Excliange Act of 1934, cll. 404, 48 Stat. 881 (codified as amended at 15 U.S.C. $\$ \S 78 \mathrm{a}-78 \mathrm{kk}$ (1982)); and the Public Utility Holding Coinpany Act of 1935 , ch. 687,49 Stat. 803 (codified as amended at 15 U.S.C. $\$ \S 79$ to $79 z-6$ (1982)). Securities Industry I, 104 S. Ct. at 2987.

92. Securities Industry I, 104 S. Ct. at 2981 ("Because commercial paper falls within the plaim language of the Act, and becanse the inclusion of commercial paper within the terms of the Act is fully consistent with the Act's purposes, we conclude that commercial paper is a 'security' under the Glass-Steagall Act.").

For a detailed discussion of the Glass-Steagall Act and commercial paper, see Note, $A$ ConductOriented Approach to the Glass-Steagall Act, 91 YALE L.J. 102, 116-20 (1981) (concluding that Board's interpretation that commercial paper is not a "security" "frustrates the objectives of the Act").

93. Justice O'Connor, joined by Justices Stevens and Breıman, dissented. Securities Industry I, 104 S. Ct. at 2992 (O'Colmor, J., dissenting).

94. Id. 
universally understood to include commercial paper. ${ }^{95}$ The dissent argued that the ineaning of a term in one statute is of dubious utility in determining the nieaning of the saine term in an independent statute because different statutory purposes may alter the definition of the term. ${ }^{96}$ The dissent analyzed the Board's interpretation and found it a reasonable-and "perhaps the inevitab[le]"97_construction of the statute.98

The second case, Securities Industry II, involved the Federal Reserve Board's decision approving the acquisition of a retail securities brokerage by a bank holding conpany. ${ }^{99}$ Two statutes presented potential bars to the inerger. ${ }^{100}$ Section 4(c)(8) of the Bank Holding Conipany Act authorizes bank holding companies to engage in non-banking activities only if those activities are "so closely related to banking . . . as to be a proper incident thereto." 101 The Board determined that coinmercial banks typically offer services identical to those provided by the particular retail securities broker involved in the nuerger, ${ }^{102}$ and therefore concluded that the activities involved were "closely related" to banking within the nreaning of section $4(\mathrm{c})(8) .{ }^{103}$

Section 20 of the Glass-Steagall Act ${ }^{104}$ posed the second potential statutory obstacle. That provision prohibits commercial banks from becoming affiliated with an organization "engaged primcipally in the issue, flotation, underwriting, public sale, or distribution . . . of stocks, bonds, debentures, notes, or other securities."105 The Board held that the target retail securities brokerage was not principally engaged in any of the activities histed in section 20.106

95. The dissent stated, 'The Glass-Steagall Act nowhere defines the term 'securities,' and the term is not so well-defined, either generally or as a legal term of art, that commercial paper is plainly included within its meaning." Id. at 2994 (O'Connor, J., dissenting). The dissent, citing to recent authorities, fonnd the terms "securities" and "notes" to be susceptible of both broad and narrow definitions. Id. (citing BlaCK's LAw DiCTIONARY 956 (5th ed. 1979) (defining "note") and ENCYClopedia of Banking and FinanCe 724-25 (G. Munn \& F. Garcia eds. 8th ed. 1983) (defining "note").

96. Securities Industry I, 104 S. Ct. at 2999-3000 (O'Connor, J. dissenting).

97. Id. at 2993.

98. Id. at 3003 O'Connor, J., dissenting.

99. Securities Industry II, $104 \mathrm{~S}$. Ct. at 3006.

100. Id. at 3006-07.

101. Bank Holding Company Act of 1956, Pub. L. No. 84-511, $\$ 4(c)(8), 70$ Stat. 133, 137 (codified as amended at 12 U.S.C. $\$ 1843(c)(8)(1982)$ ).

102. Securities Industry II, $104 \mathrm{~S}$. Ct. at 3007 . The brokerage house involved in the case was the Charles Schwab Corp., a "discount" broker that "does not provide investment advice or analysis, but inerely executes the purchase and sell orders placed by its custoners." Id. at 3005 n.2.

103. Id. at 3007 .

104. Banking Act of 1933, ch. $89, \S 20,48$ Stat. 162, 188-89 (codified at 12 U.S.C. $\S 377$ (1982)).

105. Id.

106. Securities Industry II, $104 \mathrm{~S}$. Ct. at 3007. 
The Court, in reviewing the Board's interpretation of section 4(c)(8), reasoned that because Congress failed to specify the factors used to determine whether an activity is "closely related" to banking, it "vested the Board with considerable discretion." 107 Thus, the Board's interpretation was entitled to the "greatest deference."108 The Court found that the standard applied by the Board-operational and functional similarity to services generally provided by banks-was reasonable. ${ }^{109}$

The Court also ruled that the Board's interpretation of section 20 of the Glass-Steagall Act was both reasonable and consistent with legislative intent. ${ }^{110}$ The challenge to the Board's interpretation focused on the construction of the phrase "public sale."111 The Court noted that the words used in conjunction with "public sale"- "issue, flotation, underwriting [and] distribution"112 -described the traditional functions of investment banking, not securities brokerage, and therefore the term "public sale" was used to proscribe underwriting activity. ${ }^{113}$ This interpretation was further supported by the underlying purposes of the GlassSteagall Act. Echoing the Securities Industry I decision, ${ }^{114}$ the Court noted that concerus about potential losses from securities speculation and other hazards associated with underwriting had motivated Congress to enact that statute separating commercial banks froin entities involved in underwriting. ${ }^{115}$ The Court concluded that the brokerage activity imvolved-the buying and selling of securities as an agent-did not trigger those concerus. ${ }^{116}$

The two Securities Industry opinions do employ a "Chevron"-type analysis, although neither opinion cites Chevron nor exphicitly outlines the two-step inethod of analysis. In Securities Industry I, the Court first focused on the expression of congressional intent. The majority contended that Congress could not have expressed its intent in a clearer

107. Id. at 3008.

108. Id. at 3009 (quoting Board of Governors v. Investment Co. Inst., 450 U.S. 46,56 (1981)).

109. See Securities Industry II, $104 \mathrm{~S}$. Ct. at 3008-09. The Court stated:

In this case, the Board has articulated with commendable thoroughness the ways in which banking activities are similar to the brokerage activities at issue here. The standard the Board used to determine that Schwab's brokerage business is "closely related" to banking is reasonable and supported by a normal reading of the statutory language of $\S 4(c)(8)$.

Id. at 3009.

110. Id. at 3012 .

111. Id. at 3009 .

112. Banking Act of 1933 , ch. $89, \S 20,48$ Stat. 162,188 (codified at 12 U.S.C. $\S 377$ (1982)).

113. Securities Industry II, $104 \mathrm{~S}$. Ct. at 3010.

114. See supra notes $86-89$ and accompanying text.

115. Securities Industry II, $104 \mathrm{~S}$. Ct. at 3011.

116. Id. at 3011-12. 
manner. ${ }^{117}$ Under the Chevron analysis, this would render the first step dispositive. The dissenting justices disagreed with that position, arguing that Congress did not address the precise question at issue in either the statute or the legislative history. ${ }^{118}$ The dissent then proceeded to the second step to its "Chevron"-type analysis, determining that the Board's interpretation was not inconsisent with the statutory language and the legislative history. ${ }^{119}$

Securities Industry II also illustrates the operation of the two-step analysis. The Court first recognized that the use of the ambiguous statutory term "closely related" without concurrent provision of any clarifymg definition sigualled Congress' implicit intention to vest the Board with substantial interpretive authority. ${ }^{120}$ The Court then proceeded to the second step of its analysis, reviewing the Board's statutory interpretation with the "greatest deference."121

The Securities Industry cases do not, however, apply the Chevron framework; statements im both opinions are markedly inconsistent with the Chevron analysis. ${ }^{122}$ Yet both opinions do follow the general twostep analysis, applying standards substantially equivalent to those developed in Chevron. Perhaps this is best explained by reference to Professor Monaghan's observation made while discussing the application of an analytic framework quite similar to the Chevron analysis and prior case law: "The case[s] can be rationalized on such a basis [a "Chevron"-type analysis] - whether or not all cases were in fact decided with such a clear

117. The Court believed that the Congress that passed the Glass-Steagall Act understood "securities" and "notes" to include commercial paper, and chose expansive terms in order to secure a proplyylactic effect. The Court examined the statute as well as conteinporaneous statutes and their legislative history in determining that the Congress that enacted the Glass-Steagall Act understood "securities" and "notes" to include commercial paper. See Securities Industry I, 104 S. Ct. at 298687. The Court placed great weight on stateinents made at congressional hearings, noting that at learings involving the Securities Act of 1933, Senator Glass objected to the use of the terms "security" and "note" because they plainly included commercial paper, but at hearings on the GlassSteagall Act lield two weeks later, the "eponymous" Senator Glass made no such objection to the use of the same terms. Id. at 2987. See supro notes 86-92 and accompanying text.

118. See supro notes $94-96$ and accompanying text.

119. See supra notes $97-98$ and accompanying text.

120. See supra note 107 and accompanying text.

121. See supra notes $108-09$ and accompanying text.

122. In Securities Industry I, for example, the Court states that because the position taken by the Board at oral argument was slightly different than that found in the Board's written opinion, its interpretation was not entitled to "full deference." See Securities Industry I, 104 S. Ct. at 2983-84. If the Court lad strictly followed a Chevron analysis and found no ambiguity in the statutory language, then its statements concerning "deference" were superfluous. Cf. Federal Election Comn'n v. Democratic Senatorial Campaign Comm., 454 U.S. 27, 31 (1981) (court of appeals discussion of extent of deference to agency interpretation was "pointless" if court was correct that interpretation violated plam language of statute). 
perception in mind." 123

B. Chemical Manufacturers.

In Chemical Manufacturers Association v. Natural Resources Defense Council, 124 the Supreme Court appears to have removed the doubts created by the Securities Industry cases concerning the application of Chevron. In Chemical Manufacturers, both the majority ${ }^{125}$ and dissenting ${ }^{126}$ opinions explicitly relied on Chevron as providing the proper analytic framework.

Chemical Manufacturers involved section $301(l)$ of the Clean Water Act, which prohibits the EPA from "modify[ing] any requirement of this section as it applies to any specific pollutant which is on the toxic pollutant hist."127 Section 301 requires the EPA to proinulgate regulations categorizing sources of pollution and setting effluent limitations for each category. ${ }^{128}$ Section 307 of the Act requires the agency to set effluent limitations for toxic pollutants for each category established under section 301 at a level consonate with the "best available technology economically achievable." 129 Against this statutory framework, the EPA established the requisite categories and promulgated effluent limitations for each category, 130 but provided a method by which an individual polluter could seek a "variance" from the specified limits. 131

A variance could be obtained by any interested person if data specific to an individual polluter imdicated that factors fundamentally different from those considered by the EPA im establishing the standards for the category justified a different discharge limit. ${ }^{132}$ This fundamentally

123. Monaghan, supra note 52 , at 30 .

124. 53 U.S.L.W. 4193 (U.S. Feb. 27, 1985).

125. Chemical Mfrs, 53 U.S.L.W. at 4196.

126. Id. at 4203 (Marshall, J., dissenting).

127. Clean Water Act of 1977. Pub. L. No. 95-217, §53(c), 91 Stat. 1566, 1590 (codified at 33 U.S.C. $\S 1311(l)$ (1982)) (adding $\S 301(l)$ to the Federal Water Pollution Control Act).

128. Federal Water Pollution Control Act Amendinents of 1972, Pub. L. No. 92-500, §2, 86 Stat.816, 844-845 (codified at 33 U.S.C. $§ 1311$ (b) (1982)) (adding section 301(b) to the Federal Water Pollution Control Act).

129. Clean Water Act of 1977, Pub. L. No. 95-217, $\S 53($ a)(2), 91 Stat. 1566, 1589-90 (codified at 33 U.S.C. $\S 1317$ (a)(2) (1982)) (adding section 307(a)(2) to the Federal Water Pollution Control Act).

130. The EPA acted only after prodding by the Natural Resources Defense Council. The EPA promulgated standards and established categories in comphance with a consent decrec. See Natural Resources Defense Council v. Train, 8 Env't Rep. Cas. (BNA) 2120 (D.D.C. 1976), modified sub nom. Natural Resources Defense Council v. Costle, 12 Env't Rep. Cas. (BNA) 1833 (D.D.C. 1979), modified sub nom. Natural Resources Defense Council v. Gorsuch, No. 72-2153 (D.D.C. Oct. 26, 1982), modified sub nom. Natural Resources Defense Council v. Ruckelshaus, No. 73-2153 (D.D.C. Aug. 2, 1983 \& Jan. 6, 1984).

131. See 40 C.F.R. $\S 403.13$ (1984) (fundamentally different factor (FDF) variances).

132. 40 C.F.R. $\S 403.13(b)(1)(1984)$. 
different factor (FDF) variance could be sought either to raise or to lower the applicable limit. ${ }^{133}$

Environmental and industrial organizations brought suit against the EPA, alleging that section $301(l)$, with its prohibition against "1nodifications" of toxic pollutant standards, barred the EPA from granting FDF variances to dischargers of toxics. ${ }^{134}$ Although the Fourth Circuit had earier found the statute ambiguous and accordingly deferred to the EPA's interpretation, ${ }^{135}$ the Third Circuit accepted the challengers' arguments and invalidated the regulation. ${ }^{136}$

The Supreme Court reversed the Third Circuit's decision, ${ }^{137}$ citing Chevron as establishing the proper framework for reviewing the agency's interpretation. ${ }^{138}$ Addressing the question of the first step of the Chevron analysis, the Chemical Manufacturers Court looked to the statute and concluded that a hiteral interpretation of section 301 (l)'s ban on "modifications" would cause a direct conflict with a section of the act (section 307(b)(2)) that exphicitly allows the EPA to "revise" the effluent linitations for toxics. ${ }^{139}$ The EPA argued that an FDF variance was a revision sanctioned by section $307(\mathrm{~b})(2)$ and section $301(l)$ was intended to refer to sections $301(\mathrm{c})$ and $301(\mathrm{~g})$, which explicitly allow the agency to "modify" the requirements of the section under certain circumstances. ${ }^{140} \mathrm{Be}$ cause the statute could not be read hiterally without creating an irreconcilable conflict between sections of the same act, the Court con-

133. Id.

134. National Ass'n of Metal Finishers v. EPA, 719 F.2d 624, 636, 643 (3d Cir. 1983) (consolidation of sixteen separate suits), rev'd sub nom. Chenical Mfrs. Ass'n v. Natural Resources Defense Council, 53 U.S.L.W. 4193 (U.S. Feb. 27, 1985).

135. See Appalachian Power Co. v. Train, 620 F.2d 1040, 1047-48 (4th Cir. 1980) (upholding FDF variances as applied to toxics).

136. Metal Finishers, 719 F.2d at 644-46.

137. Chemical Mfrs., 53 U.S.L.W. at 4198.

138. Id. at 4196.

139. Id. Section 307(b)(2) provides: "The Administrator shall, from tine to time, as control teehnology, processes, operating methods, or other alternatives change, revise such standards following the procedure established by this section for promulgation of such standards." 33 U.S.C. $\S 1317(b)(2)(1982)$ (section 307(b)(2) of the Federal Water Pollution Control Act). Section $301(l)$ provides: "The Administrator may not modify any requirement of this section as it applies to any specific pollutant which is on the toxic pollutant list under section 1317(a)(l) of this title." 33 U.S.C. $\S 1311(l)$ (1982) (section 301 $(l)$ of the Federal Water Pollution Control Act).

140. Chemical Mfrs, 53 U.S.L.W. at 4196-97. Seetion 301(c) authorizes the EPA to modify the standards established for a category of dischargers as they apply to a specific discharger upon a showing by the owner or operator of a plant of maximum use of technology within the economic capability of the owner or operator and reasonable progress toward the ehimination of the discharge of pollutants. 33 U.S.C. $\S 1311$ (c) (1982) (section 301(c) of the Federal Water Pollution Control Act). Seetion $301(\mathrm{~g})$ authorizes modification upon a showing that the modification will not adversely affect water quality, aquatic wildlife, or human hcalth. 33 U.S.C. $\S 1311(\mathrm{~g})(1982)$ (section $301(\mathrm{~g})$ of the Federal Water Pollution Control Act). 
cluded that the term "modify ... has no plain meaning as used in $\S 301(l)$, and is the proper subject of construction by EPA and the courts."141

Turning to the legislative history, the Court found nothing indicating an intent to forbid FDF waivers. ${ }^{142}$ The Court noted that although section 301(l) was added in conference, the conference committee report failed to explain its inclusion. ${ }^{143}$ The Court found this silence to be significant. In E.I. $d u$ Pont de Nemours \& Co. v. Train, ${ }^{144}$ the Court had suggested that FDF variances were a permissible regulatory mechanism. The Court reasoned that because the $D u$ Pont decision was announced several months before the conference committee added section 301(l), it certainly would have been "odd" for the committee to include im the act language that reversed the thrust of a recent Supreme Court decision and then fail to communicate its intent to either house. ${ }^{145}$

Further, the Court noted that although several legislators had used the terms "waivers," "modifications," and "variances" interchangeably in debate, 146 the inanager of the bill in the House explanied section $301(l)$ in a manner directly supporting the agency's interpretation. ${ }^{147}$ The Court concluded that the legislative history did not evince a clear congressional intent to preclude the use of FDF variances with respect to toxic pollutants and accordingly proceeded to the second step of the Chevron analysis. ${ }^{148}$

In applying the second step of the analysis, the Court first asked whether the FDF variance mechanism would "frustrate the goals and operation of the statutory scheine." 149 The Court reasoned that because the FDF variance procedure allows the EPA to consider factors peculiar to an individual discharger that may not have been sufficiently weighed in drafting the standards for a category of polluters, the variance mecha-

141. Chemical Mfrs., 53 U.S.L.W. at 4196.

142. Id. at 4197.

143. Id. at 4196 .

144. 430 U.S. 112, 127-28 (1977).

145. Chemical Mfrs., 53 U.S.L.W. at 4196-97.

146. Id. at 4197 (citing statements of Sen. Muskie, Senate manager of the bill and Rep. Roberts, House manager of the bill).

147. The Court quoted Representative Roberts, the House floor manager, who in explaining section $301(l)$ stated:

Due to the nature of toxic pollutants, those identified for regulation will not be subject to waivers from or modification of the requirements prescribed under this section, specifically neither section 301(c) waivers based on economic capability of the discharger nor 301(g) waivers based on water quality considerations shall be available.

Id. at 4196 (emphasis supplied by the Court) (quoting 123 Cong. Rec. 38,960 (1977) (statement of Rep. Roberts)).

148. Id. at 4197.

149. Id. 
nisin is "not an exception to the standard-setting process] commanded by section 307], but rather a nore fine-tuned application of it." 150 Recognizing this, the CQurt stated that the dispute essentially centered on the nieans employed by the EPA in defining the standards for subcategories of polluters and could be summarized simply as an argument between differing policies. ${ }^{151}$ The Court concluded that because the EPA's interpretation was not inconsistent with the language, legislative history, and operation of the Act, it was entitled to deference. ${ }^{152}$

Unlike Chevron, the Chemical Manufacturers decision was not unanimous; four justices mcluding Justice Stevens, the autlior of Chevron, joined in dissent. ${ }^{153}$ The dissent, however, agreed with the najority in explicitly adopting the Chevron analysis. ${ }^{154}$ The disagreement arose in the application of the first-step test-whether "Congress clearly intended that $\S 301(l)$ do nore than just ban modifications otlierwise permitted by $\S 301(\mathrm{c})$ and $(\mathrm{g}) \ldots . . .155$

Justice Marshall, writing for the dissenters, noted that althougli the statute does not explicitly define "modifications," there is nothing on the face of section 301 ( $l$ ) fron which to infer that its prolibition is qualified. ${ }^{156}$ Further, the legislative history of the provision not only failed to provide support for the EPA's narrow interpretation of "nıodify," but evidenced a "clear congressional intent" to ban all modifications. ${ }^{157}$ The dissent cited statenients of congressinen, inade on the floor, indicating that Congress im drafting the 1977 amendments was deeply concerned with the probleins presented by toxic pollutants. ${ }^{158}$ Several congressmen realized that the statutory prohibitions of toxic pollution would lead to extreinely restrictive regulation of imdustry, resulting im costs to industry of "millions of dollars."159 The dissent explained that congressional

150. Id.

151. Id. The Court made implicit reference to Chevron in discussing the role of the courts in reviewing an agency's policy choice:

Here we are not dealing with an agency's change of position with the advent of a different administration, bnt rather with EPA's consistent interpretation since the the [sicl 1970s. NRDC aruges that its construction of the statute is better supported by policy considerations. But we do not sit to judge the relative wisdon of competing statutory interpretations.

Id. at 4198.

152. Id. at 4198.

153. Id. at 4198 (Marshall, J., dissenting).

154. Id. at 4203 (Marshall, J., dissenting).

155. Id. (Marshall, J., dissenting).

156. Id. at 4200 (Marshall, J., dissenting).

157. Id. at 4199 (Marshall, J., dissenting).

158. Id. at 4200 (Marshall, J., dissenting) (citing remarks of Sen. Muskie and Rep. Roberts).

159. Id. at 4200 (Marshall, J., dissenting) (quoting 123 Cong. Rec. 38,952 (1977) (statement of Rep. Roberts)). 
awareness of the tremendous costs that would be imposed or industry led to the inclusion of section 301(c), which tempered the requirements of section 301 where strict adherence would cause bankruptcy. ${ }^{160}$ The dissent saw the same congressional concern as motivating the modification provision of section $301(\mathrm{~g}){ }^{161}$ Marshall then reasoned that because Congress had provided modification procedures only where the social concern was great, the EPA interpretation of section $301(l)$ that barred modifications 1mder sections $301(\mathrm{c})$ and $301(\mathrm{~g})$ - where the social concern was the greatest-but allowing modifications as FDF variances"the least compelling case for inodification"-was "wholly counterintuitive."162 Turning to statements made by congressmen in debate, the dissent found support for its interpretation of section $301(l)$. The dissent cited statements of both the manager of the bill in the House and the manager in the Senate to the effect that requirements for toxic pollutants could not be waived. ${ }^{163}$

The dissent found the majority's rehance on Congress's failure to amend the Act to reverse exphicitly the Court's decision in E.I. duPont de Nemours v. Train, ${ }^{164}$ which sanctioned the EPA's use of FDF variances, ${ }^{165}$ unfounded. In Dupont, the dissent argued, the Court upheld the EPA's use of FDF variances where the statute provided for regulation of "point sources."166 Yet for toxic pollutants, the statute requires regulation " "for the applicable category or class of poimt sources." "167 The dissent concluded that because Dupont had merely sanctioned a regulatory device-FDF variances-that adjusted standards for specific poimt source where the statute commanded regulation of poimt sources, it did not send a message to Congress that the same regulatory device was appropriate where the statute required regulation by category. ${ }^{168}$ Thus congressional failure to act on Dupont was not significant. ${ }^{169}$

Further, the dissent concluded that because the Act conteinplates revision of standards of toxic effluents by categories of polluters, ${ }^{170}$ the

160. Chemical Mfrs., 53 U.S.L.W. at 4200 (Marshall, J., dissenting). For a discussion of section 301(c), see supra note 142.

161. Chemical Mfrs, 53 U.S.L.W. at 4200 (Marshall, J., dissenting). For a discussion of section $301(\mathrm{~g})$, see supra note 140.

162. Chemical Mfrs, 53 U.S.L.W. at 4201 (Marshall, J., dissenting).

163. Id. at $4202-03$ (Marshall, J., dissenting).

164. 430 U.S. 112 (1977).

165. Chemical Mfrs, 53 U.S.L.W. at 4202 (Marshall, J., dissenting).

166. Id. (Marshall, J., dissenting).

167. Id. at 4202 (emphasis supphied by Marshall, J., dissenting) (quoting 33 U.S.C. $§ 1317$ (a)(2) (1982)).

168. Chemical Mfrs, 53 U.S.L.W. at 4202 (Marshall, J., dissenting).

169. Id. (Marshall, J., dissenting).

170. See 33 U.S.C. $\$ 1317(b)(2)-(3)$ (1982). 
FDF variance nechanism, which effectively provides for plant-by-plant regulation, is wholly imappropriate. ${ }^{171}$ The dissent noted that Congress called for regulation by categories as a "means to 'force' the introduction of more effective pollution control technology" because in establishing the effluent standards for a category, EPA was to look to the "best performer" in that category. ${ }^{172}$ To allow a discharger an FDF variance would frustrate the congressional goal of forcing the discharger to develop more effective pollution control technology. ${ }^{173}$ Accordingly, the dissent concluded that Congress had "clearly intended that $\S 301(l)$ ban variances such as those at issue here."174

The dissent emphasized that its analysis was the Chevron analysis, but "Chevron's deference requirement . . . was explicitly limited to cases in which congressional intent cannot be discerned through the use of traditional techniques of statutory interpretation." ${ }^{175}$ Justice Marshall made that point clear:

My disagreement with the Court does not center on its reading of Chevron, but instead on its analysis of the congressional purposes behind $\S 301(l)$. If I agreed with the Court's analysis of the statute and the legislative history, I too would conclude that Chevron commands deference to the administrative construction. ${ }^{176}$

Chemical Manufacturers sheds significant light on the question that Chevron failed to illuminate: what is the standard in judging "whether Congress has directly spoken to the precise question at issue[?]"177 In Chemical Manufacturers, the statute did not define the term at issue; 178 the term was a part of a section added in conference ${ }^{179}$ and the conference report failed to discuss the impact of the added section. ${ }^{180}$ On all these points, the majority and dissent agreed. The disagreenient arose over the intensity of the justices' searcli for a "clear congressional intent."

The majority first noted the facial conflict between section $301(l)$ prohibitimg "modifications"-and section 307(b)(2)-allowing "revision[s]." 181 This conflict, the Court stated, made the term "modify" "the

171. See Chemical Mfrs., 53 U.S.L.W. at 4203-05 (Marshall, J., dissenting).

172. Id. at 4204 (Marshall, J., dissenting).

173. Id. (Marshall, J., dissenting).

174. Id. at 4205 (Marshall, J., dissenting).

175. Id. at 4203 (Marshall, J., dissenting).

176. Id. (Marshall, J., dissenting).

177. Chevron, U.S.A., Inc. v. Natural Resources Defense Council, 104 S. Ct. 2778, 2781 (1984).

178. Chemical Mfrs, 53 U.S.L.W. at $4196,4200$.

179. Id. at 4196, 4201 (Marshall, J., dissenting).

180. Id.

181. Id. at 4196. 
proper subject of construction by EPA and the courts." 182 The Court then failed to find any explicit statement made by any congressional body that precluded the EPA's interpretation. ${ }^{183}$ To the Court, the facial conflict between the provisions coupled with the failure of any congressional body to explain the intended scope of the term "modify" was sufficient evidence that Congress had not addressed the precise question at issue.

The dissent argued that the majority failed to find a "clear congressional intent" because it failed to examine the statute in light of its general purpose. ${ }^{184}$ To the dissenting justices, Congress was concerned only with the dangers of toxic pollutants and sought regulation in spite of the cost to industry. ${ }^{185}$ After thus identifying the "congressional purpose," the dissent noted "that a complete ban on inodifications would inost directly and coinpletely accoinphish the congressional goal."186 Clearly the difference between the analyses of the majority and dissent is the use of "congressional purpose."

Chevron does not explicitly sanction either view. The Chevron Court in examining the legislative history of the statute found no "specific cominent on the 'bubble concept' or the question whether a plantwide definition of a stationary source is permissible."187 The Court then stated that the legislative history did reveal Congress's "two main purposes" in enactimg the statute. ${ }^{188}$ However, the Chevron Court gave no indication that consideration of the "purpose" of the statute would be a judicially permissible way of determining whether Congress spoke to the precise question at issue. 189

However, Chevron implies that "clear congressional intent" is not expressed when a court must resort to the general purposes of the statute in order to resolve the interpretive question. In Chevron, the Court reversed a decision in which the court of appeals interpreted the term "source" by considering the general purpose of the statute in which it appeared, ${ }^{190}$ even though it had concluded that Congress had not explic-

182. Id.

183. See id. at 4196-97 (finding nothing in legislative history that evinces an unambiguous congressional intention).

184. Id. at 4200 (Marshall, J., dissenting).

185. Id. at 4199-4200, 4202-03 (Marshall, J., dissenting).

186. Id. at 4200 (Marshall, J., dissenting).

187. Chevron, 104 S. Ct. at 2786.

188. Id. (clean environment and continued economic growth).

189. In indicating that the legislative history revealed the statute to be the product of conflicting policy objectives, the Court did not indicate the relevancy of this observation to the issue of whether Congress directly spoke to the precise question. See id.

190. Natural Resources Defense Council v. Gorsuch, 685 F.2d 718, 726-27 (D.C. Cir. 1982), rev'd sub nom. Chevron, U.S.A., Inc. v. Natural Resources Defense Council, 104 S.Ct. 2778 (1984). The court of appeals relied on two prior decisions that had involved the EPA's interpretation of 
itly defined the term and the issue was not "squarely addressed in the legislative history." 191 The Chevron Court deemed this a "basic legal error." 192

Further, a judicial finding that Congress had directly spoken to the precise question resting on arguments developed in considering the general purposes of the statute violates the fundainental teaching of Chevron. As the Court has inade clear on several occasions, a statute represents a compromise of conflicting purposes and policies. ${ }^{193}$ Thus for a court to determine the congressional purpose in enacting a statute, it must weigh the various policies present in the compromise. It is this type of judicial balancing that Chevron clearly forbids. ${ }^{194}$ Chemical Manufacturers clarifies what was miplicit in Chevron-that reasoning from the general purposes of the statute is not one of the "traditioonal tools of statutory construction"195 to be einployed in determining whether Congress directly spoke to the precise question at issue. ${ }^{196}$

source-Alabama Power Co. v. Costle, 636 F.2d 323 (D.C. Cir. 1979), and ASARCO, Inc. v. EPA, 578 F.2d 319 (D.C. Cir. 1978). Natural Resources Defense Council v. Gorsuch, 685 F. 2d 718, 72526 (D.C. Cir. 1982), rev'd sub nom. Chevron, U.S.A., Inc. v. Natural Resources Defense Council, $104 \mathrm{~S}$. Ct. 2778 (1984). The court read these two cases as requiring a bifurcated interpretation of the term "source" as it was used in different sections of the act, allowing the "bubble concept" where the purpose of the provision was to maintain air quality, disapproving of it where the purpose was to improve air quality. Id. The court concluded that simce the general purpose of the provision involved-its "raison d'etre"-was to improve air quality, the EPA's use of the "bubble concept" was imappropriate. Id. at 726-28.

191. Natural Resources Defense Council v. Gorsuch, 685 F. 2d 718, 723 (D.C. Cir. 1982), rev'd sub nom. Chevron U.S.A., Inc. v. Natural Reseources Defense Council, 104 S. Ct. 2778 (1984).

192. Chevron, $104 \mathrm{~S}$. Ct. at 2781. The Court stated: "The basic legal error of the Court of Appeals was to adopt a static judicial definition of the term stationary source when it had decided that Congress itself had not commanded that definition." Id. The "static judicial definition" was developed by considering the general purpose of the statute. See supra note 190.

193. See supra note 68. Indeed, in section 307 of the Clean Water Act, Congress was concerned with more than the protection of human health. If that was its sole concern it would have required zero-discharge levels for toxics instead of limiting the level to the "best available technology econoinically achievable." 33 U.S.C. § 1317(a)(1) (1982) (standard for toxic effluents).

194. See supra text accompanying note 65 .

195. Chevron, 104 S. Ct. at 2782 n.9.

196. This view is in accord with the "clear statement" unodel developed to explain recent Supreme Court cases involving statutory interpretation. See Note, supra note 68, at 899-904. The commentator notes that "judicial reliance on legislative purpose-the touchstone of those recently abandoned modes of interpretation-is now perceived as usurpation of legislative power that produces both illegitimate and incompetent judicial interference in statutory schemes." Id. at 900 (footnotes orritted). If this is truely the Court's view of statutory interpretation, the first step of the Chevron analysis may require an explicit congressional statement of the meaning of statutory terms in order to find an "unambiguously expressed intent." 


\section{CONCLUSION}

In the study of judicial review, it is wise to remember that commentators present models as attempts to explain the thought processes of judges as manifested in court opinions. Because opinions do not always articulate the actual analyses employed, ${ }^{197}$ models of judicial review are developed by extrapolatimg a logical frainework from the actions of a court. Although these extrajudicial models suffer from this inherent flaw, they often provide the only guidance to lower courts to determine the proper analytic framework for structuring review. Thus it is highly significant when the Supreme Court does articulate an analytic framework.

In Chevron, the Court presented a framework for structuring judicial review that provides meaningful review while prohibiting judicial infringement on an agency's legitimate authority. The two-step analysis ensures that the governmental bodies charged with inaking policy decisions-Congress and the agencies-will actually make those decisions and that the adinittedly ill-equipped courts will abstain. ${ }^{198}$ Furthermore, by extending the interstitial lawmaking model to implicit delegations of interpretive authority, Chevron focuses judicial inquiry on two separate issues. Chevron avoids the inherent confusion created when a court attempts to balance its independent perception of the proper statutory construction and its deference to the agency's interpretation. Chevron directs the court to ask imitially whether Congress, in drafting the statute, dealt with the interpretive issue; if Congress did not, then the court examines the agency's interpretation to determine whether the agency has properly exercised its legitimate interstitial lawmaking authority by adopting an interpretation that is reasonably supported by the statute and legislative history. ${ }^{199}$

As noted previously, the heart of the Chevron analysis is the judicial determination whether Congress has "unambiguously" expressed its intent. Chemical Manufacturers provides greater meaning to the "unambiguous" standards indicating that the Court will not look to the general

197. See DAVIS, 1982 SuPPLEMENT, supra note $1, \S 29.00-6$, at 562-63 (many opinions refuse to clarify choice between rational basis test and "rightness" approach).

198. The Court stated:

[A]n agency to which Congress has delegated policy-making responsibilities may, within the limits of that delegation, properly rely upon the incumbent administration's views of wise policy to inform its judgments. While agencies are not direetly accountable to the people, the Chief Exeeutive is, and it is entirely appropriate for this political brancli of governinent to inake sucli policy clioices-resolving the coinpeting interests whicli Congress itself either madvertently did not resolve, or intentionally left to be resolved by the agency clarged with the administration of the statute in light of everyday realities.

Chevron, 104 S. Ct. at 2793. See supra notes 63-77 and accompanying text.

199. See Chevron, 104 S. Ct. at 2781-82. 
purposes of the statute in determining whether Congress has clearly expressed its intent. Yet even this apparently simple standard conceals a fundamental uncertainty. In innumerable cases, the justices of the Supreme Court have arrived at opposite conclusions regarding the meaning of the saine statute without relymg on an argument concerning the general purposes of the statute; ${ }^{200}$ a shight alteration in the focus of inquiry affords no basis to expect sudden unanimity of judgment. The significance and the purpose of the Chevron analysis, however, is not to foreordain the outcome of a particular case, but to focus the inquiry on the appropriate questions. ${ }^{201}$

Although Chemical Manufacturers demonstrates the potential significance of Chevron, the true significance of the decision depends on subsequent case development. Certainly, Chevron contains a message both for the lower courts and for Congress. ${ }^{202}$ Courts are to avoid excessive interference in agency policy choices, while Congress should avoid drafting broad delegations to agencies in vague statutes, expecting the courts to control the interpretation of anbiguous statutory terms. ${ }^{203}$ However, the force of these inessages depends upon the Court's exphicit adherence to Chevron.

Stephen M. Lynch

200. Some recent examples are: Jefferson County Pharmaceutical Ass'n v. Abbott Laboratories, 460 U.S. 150 (1983) (interpretation of $\S 13$ of Robinson-Patman Act; five justices vote to reverse court of appeals, four dissent in two opinions); American Tobacco Co. v. Patterson, 456 U.S. 63 (1982) (construction of Title VII of Civil Rights Act of 1964; five justices vote to reverse court of appeals, four dissent in two opinions); NLRB v. Amax Coal Co., 453 U.S. 322 (1981) (interpretation of provision of Labor-Management Relations Act; eight justices vote to reverse court of appeals, one dissents); Watt v. Alaska, 451 U.S. 259 (1981) (issue was whether 1964 statute superseded 1920 act; six justices vote to affirm court of appeals, with one concurring separate opinion, three dissent).

201. The purpose of the Chevron analysis, as is true of any analytical framework, is not to predestine the decision of any controversy: "The test channels the search for an answer but the answer ultimately depends on the appreciation of the particular judge." Jaffe, supra note 1, at 264.

202. See DeLong, supra note 36, at 7 (Chevron contains messages to courts about perceived judicial overintrusiveness and to Congress regarding control of agencies given broad and amorphous delegations).

203. Id. 